\title{
Perancangan Decision Support System Penilaian Kinerja Dosen Berdasarkan Penilaian Prestasi Kerja Pegawaidan Beban Kinerja Dosen
}

\author{
Rizal Furqan Ramadhan, Herman Tolle, Muhammad Aziz Muslim
}

\begin{abstract}
The lecturer is one of the essential components in the Higher Education system. Performance assessment of lecturer needs to be conducted to measure the lecturer capability based on the Tri Darma's Higher Education concept. Related to the nowadays technology development, to conduct performance assessment of lecturer can use the Decision Support System based on several criteria as the assessment material. The provided criteria in this paper seem to be the obtained criteria from P2KP and BKD component. P2KP is performance assessment of lecturer under the Badan Kepegawaian Negara (BKN) supervision. Meanwhile BKD is performance assessment of lecturer under the DIKTI supervision. The lecturer criteria are taken from those two components because the lecturers' status cannot be separated from the officer under BKN and educator under the DIKTI support. It is expected that the criteria coming from both components integration will be able to produce performance assessment of lecturer objectively. The method to proceed the assessment was Weighted Product (WP). The examined data of the lecturers were the Brawijaya University lecturers' data. The final examination data was conducted by taking the data randomly from 20 Brawijaya University lecturers. The final output from this Decision Support System is the lecturers which are selected from three categories, which are, less, normal, and good. It is expected that Decision Support System is able to categorize the standard eligible lecturer (Normal/medium category), and the lecturer surpassing the standard (good category).
\end{abstract}

Index Terms-Performance assessment of lecturer, Decision Support System, P2KP, BKD, Weighted Product

Abstrak-- Dosen merupakan salah satu komponen esensial dalam suatu sistem pendidikan di perguruan tinggi. Penilaian kinerja dosen perlu dilakukan untuk mengukur sejauh mana kapasitas seorang dosen sesuai dengan konsep Tridharma Perguruan Tinggi. Sesuai

Rizal Furqan Ramadhan is with the Electrical Engineering Departement of Universitas Brawijaya, Malang, Indonesia (email: rizal furqan@yahoo.co.id)

Herman Tolleis with the Informatic Engineering Departement of Universitas Brawijaya, Malang, Indonesia (email: emang@ub.ac.id )

Muhammad Aziz Muslim is with the Electrical Engineering Departement of Universitas Brawijaya, Malang, Indonesia (email: muh_aziz@ub.ac.id ) dengan perkembangan zaman sekarang yang berbasis teknologi, untuk melakukan penilaian kinerja dosen dapat menggunakan sebuah Decision Support System berdasarkan beberapa kriteria sebagai bahan penilaian. Kriteria yang disediakan pada paper ini merupakan kriteria yang diambil dari komponen P2KP dan komponen BKD. P2KP merupakan penilaian kinerja dosen dibawah pengawasan Badan Kepegawaian Negara (BKN) sedangkan BKD merupakan penilaian kinerja dosen dibawah pengawasan DIKTI. Kriteria dosen diambil dari kedua komponen tersebut karena status seorang dosen tidak lepas dari pegawai dibawah naungan Badan Kepegawaian Negara dan tenaga pendidik dibawah naungan DIKTI. Diharapkan kriteria yang berasal dari integrasi keduanya mampu menghasilkan penilaian kinerja dosen yang objektif. Metode untuk memproses penilaian yakni Weighted Product (WP). Data dosen yang dilakukan pengujian adalah data dosen di Universitas Brawijaya. Pengujian akhir dilakukan dengan mengambil data sebanyak 20 dosen Universitas Brawijaya secara acak. Hasil akhir/keluaran dari Decision Support System ini adalah dosen yang dipilah menjadi 3 kategori yakni Kurang, sedang/normal dan baik. Diharapkan dengan adanya Decision Support System ini mampu mengkategorikan dosen yang sudah masuk standar (Kategori Sedang/Normal) dan dosen yang sudah melewati batas standar (Kategori Baik).

Kata Kunci- Kinerja Dosen, Decision Support System, P2KP, BKD, Weighted Product

\section{PENDAHULUAN}

$\mathrm{D}$ osen adalah salah satu komponen esensial dalam suatu sistem pendidikan di perguruan tinggi [1]. Sebagaimana diamanatkan dalam UU Nomor 14 Tahun 2005 tentang Guru dan Dosen, dosen dinyatakan sebagai pendidik profesional dan ilmuwan dengan tugas utama mentransformasikan, mengembangkan, dan menyebarluaskan ilmu pengetahuan, teknologi, dan seni melalui pendidikan, penelitian, dan pengabdian kepada masyarakat (Bab 1 Pasal 1 ayat 2) [1]. Kompetensi tenaga pendidik, khususnya dosen, diartikan sebagai seperangkat pengetahuan, keterampilan dan perilaku yang harus dimiliki, dihayati, dikuasai dan diwujudkan oleh dosen dalam melaksanakan tugas profesionalnya. Kompetensi tersebut meliputi kompetensi pedagogik, 
kompetensi kepribadian, kompetensi sosial dan kompetensi profesional [1].

Untuk mewujudkan dosen yang profesional dibutuhkan penilaian sebagai proses evaluasi atas kinerja yang dilakukan oleh setiap dosen. Sesuai dengan PP No 10 Tahun 1979 Pelaksanaan Penilaian Kinerja Pegawai tertuang dalam Daftar Penilaian Pekerjaan Pegawai Negeri Sipil atau yang lebih dikenal dengan DP3 PNS. Namun DP3 PNS tersebut memiliki banyak kelemahan, kelemahan yang utama dari DP3 adalah tidak dapat digunakan dalam menilai dan mengukur seberapa besar produktivitas dan kontribusi PNS terhadap organisasi [2]. Hal ini disebabkan penilaian prestasi kerja pegawai dengan menggunakan metode DP3 tidak didasarkan pada target tertentu, sehingga disempurnakan dengan Penilaian Prestasi Kerja Pegawai Negeri Sipil [2].

Penilaian kinerja dosen sebagai pegawai dibawah pengawasan Badan Kepegawaian Negara dibahas dalam Peraturan Pemerintah Republik Indonesia Nomor 46 Tahun 2011 Tentang Penilaian Prestasi Kerja Pegawai Negeri Sipil. Penilaian prestasi kerja PNS dilaksanakan oleh Pejabat Penilai sekali dalam 1 (satu) tahun yang dilakukan setiap akhir Desember pada tahun yang bersangkutan atau paling lama akhir Januari tahun berikutnya. Penilaian prestasi kerja PNS terdiri atas unsur SKP dengan bobot nilai $60 \%$ dan Perilaku kerja dengan bobot nilai 40\% [3].

Penilaian Kinerja Dosen dibawah pengawasan Direktorat Jenderal Pendidikan Tinggi Kementerian Pendidikan Nasional dan Kebudayaan memiliki peraturan tersendiri yang dikenal dengan istilah Beban Kinerja Dosen (BKD).Para calon dosen untuk diakui sebagai dosen harus terdaftar sebagai dosen tetap baik di lingkungan Kemendikbud maupun non Kemendikbud (PP 37/2009 pasal 8 butir (d) ) bukti terdaftar ini dinyatakan dengan memiliki Nomor Induk Dosen Nasional (NIDN), untuk mendapatkan NIDN maka calon dosen harus dievaluasi oleh Tim Evaluasi Dari Ditjen Dikti [1].

Sesuai uraian diatas, pada paper ini dipaparkan sebuah Decision Support Sytem Penilaian Kinerja Dosen dengan kriteria yang berasal dari P2KP dan BKD. Kriteria dari P2KP digunakan karena status seorang dosen tidak lepas dari pegawai pendidik dalam sebuah universitas, sedangkan kriteria BKD digunakan karena sistem ini dipergunakan untuk dosen itu sendiri. Selain itu, P2KP digunakan sebagai kriteria dikarenakan model penilaian ini merupakan penyempurnaan dari DP3 yang sebelumnya telah diuraikan pada paper ini. Metode yang digunakan untuk menghitung proses matematis penilaian yakni metode Weighted Product. Metode Weighted Product merupakan metode yang mengunakan perkalian untuk menghubungkan rating atribut, di mana rating setiap atribut harus dipangkatkan terlebih dahulu dengan bobot atribut yang bersangkutan, proses ini sama halnya dengan proses normalisasi [4]. Pada penelitian sebelumnya yang dilakukan oleh Remigiusz OLEJNIK menyebutkan bahwa metode Weighted Product mampu membuat sebuah keputusan pemilihan produk terbaik berdasarkan nilai bobot masing - masing kriteria [5].
Hasil akhir pada Decision Support Sytem berupa keputusan dengan pengelompokan dosen berdasarkan 3 kategori yakni Dosen kategori kurang, dosen kategori sedang/normal dan dosen kategori baik. Dengan adanya pengelompokan berdasarkan kategori diharapkan dosen yang dinilai telah memenuhi standar penilaian sesuai dengan kriteria pada P2KP dan BKD.

\section{DECISION SUPPORT SYSTEM}

\section{A. Decision Support System}

Decision Support System (DSS) adalah sistem berbasis komputer yang menyajikan dan memproses informasi yang memungkinkan pembuatan keputusan menjadi lebih produktif, dinamis dan inovatif [6].Decision Support System diidentifikasi sebagai suatu sistem yang berfungsi untuk mendukung manajerial pengambil keputusan dalam situasi keputusan semi terstruktur [7]. Pada kasus yang dipaparkan di penelitian ini, kasus yang akan diproses menggunakan Decision Support System adalah kinerja dosen. Komponen Decision Support System terdiri dari beberapa subsistem antara lain [7] :

- Data Management : DSS berfungsi sebagai tempat penyimpanan data yang relevan dengan kebutuhannya yang didukung dengan sebuah aplikasi penyimpanan data yang dikenal dengan istilah DBMS.

- Model Management Subsistem : Subsistem ini sering disebut model base management system (DBMS). Subsistem ini adalah paket perangkat lunak yang mencakup keuangan, statistik, ilmu manajemen, atau model kuantitatif yang memberikan kemampuan analitis sistem.

- User Interface subsystem : Dengan subsistem ini user/pengguna dapat berkomunikasi dengan DSS karena seorang user dianggap sebagai bagian dari sistem.

- Knowledge-based management subsystem : Kecerdasan buatan yang diimplementasikan pada DSS mampu untuk membantu decision maker (pengambil keputusan) untuk mengambil sebuah keputusan.

\section{B. Weighted Product}

Pada paper ini metode yang digunakan adalah metode Weighted Product. Pada metode ini setiap alternatif dibandingkan dengan yang lain dengan mengalikan sejumlah rasio, satu untukmasing-masing kriteria. Setiap rasio dinaikkan untuk menyetarakan bobot dari masing - masing kriteria yang sesuai [8]. Hasil perkalian penilaian setiap atribut belum bermakna sebelum dibandingkan (dibagi) dengan nilai standar, dalam hal ini alternatif ideal sering digunakan sebagai nilai standar. Bobot untuk atribut manfaat berfungsi sebagai pangkat positif dalam proses perkalian antara atribut, sementara bobot berfungsi sebagai pangkat negatif bagi atribut biaya. Preferensi untuk alternative $\mathrm{Si}$ diberikan sebagai berikut :

$$
S_{i}=\prod_{j=1}^{n} X_{i j}{ }^{w j}
$$


dengan :

$\mathrm{S}=$ Preferensi alternatif dianologikan sebagai vektor $\mathrm{S}$

$\mathrm{X}=$ Nilai kriteria

$\mathrm{W}=$ Bobot kriteria / subkriteria

$\mathrm{i}=$ Alternatif

$\mathrm{j}=$ Kriteria

$\mathrm{n}=$ Banyaknya kriteria

Dimana $\sum w j=1$ serta $w j$ adalah pangkat bernilai positif untuk atribut keuntungan dan bernilai negatif untuk atribut biaya. Preferensi relatif dari setiap alternatif diberikan sebagai berikut :

dengan :

$$
V_{i}=\frac{\prod_{j=1}^{n} X_{i j}{ }^{w j}}{\prod_{j=1}^{n}\left(X_{j}{ }^{*}\right)}
$$

$\mathrm{V}=$ Preferensi alternative dianalogikan sebagai vektor $\mathrm{V}$ $\mathrm{X}=$ Nilai kriteria

$\mathrm{W}=$ Bobot kriteria dan sub kriteria

$\mathrm{i}=$ Alternatif

$\mathrm{j}=$ Kriteria

$\mathrm{n}=$ Banyaknya kriteria

* = Banyaknya kriteria yang telah dinilai oleh vektor S

\section{PERANCANGAN DECISION SUPPORT SYSTEM}

Tahapan penelitian ini antara lain dimulai dari studi literatur, kemudian dilanjutkan dengan pengumpulan data, analisis kebutuhan, desain sistem, pembuatan sistem, pengujian sistem, implementasi sistem. Dengan rangkaian tahapan tersebut diharapkan penelitian yang dilakukan fokus pada permasalahan yang dibahas dan berurutan. Permasalahan yang dimaksud mengenai kinerja dosen dengan penyelesaian menggunakan sebuah Decision Support System dengan metode Weighted Product. Berurutan pada dasarnya satu tahapan penelitian harus diselesaikan terlebih dahulu sebelum masuk ke tahapan penelitian selanjutnya, karena antara satu tahapan dengan tahapan yang lain saling berhubungan.

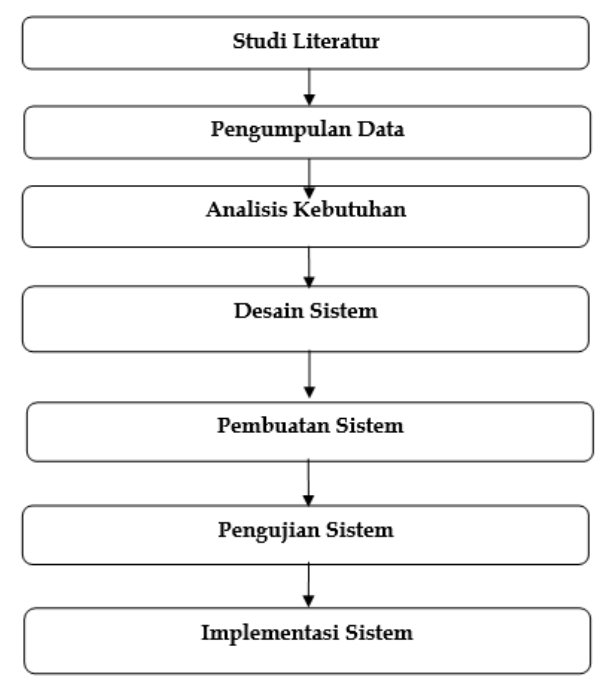

Gambar 1. Tahapan Penelitian

Sesuai pada Gambar 1, tahapan dimulai dari studi literatur. Studi literatur disini merupakan pengumpulan referensi baik jurnal nasional dan internasional yang berhubungan Decision Support System dan metode Weighted Product pada penelitian ini.

Tahapan pengumpulan data adalah proses mengumpulkan sumber data yang terdiri dari dua sumber yakni sumber data primer dan sumber data sekunder. Sumber data primer pada penelitian ini merupakan data dosen Universitas Brawijaya sedangkan daftar kriteria sebagai parameter berasal dari komponen P2KP (Penilaian Prestasi Kerja Pegawai) dan BKD (Beban Kinerja Dosen). Sumber data sekunder terdiri dari jurnal nasional dan internasional yang berhubungan dengan penilaian kinerja dosen atau mengenai Decision Support System.

Tahapan analisis kebutuhan dilakukan dengan mengidentifikasi segala kebutuhan dari sistem. Sumber data adalah komponen dari analisis kebutuhan. Dibutuhkan juga tahapan identifikasi operasional variabel penelitian DSS kinerja dosen. Tahapan identifikasi operasional variabel bertujuan untuk mengidentifikasi seluruh variabel yang berhubungan dengan penelitian yang dilakukan. Variabel pada penelitian ini adalah variabel yang berkaitan dengan penilaian kinerja dosen antara lain P2KP dan BKD.

Tahapan desain sistem terdapat arsitektur dari Decision Support System penilaian kinerja dosen yang menggambarkan komponen dari sistem ini.

Arsitektur sesuai Gambar 2 menggambarkan komponen - komponen yang ada dalam Decision Support System Penilaian Kinerja Dosen berbasis web. PHP dan MySQL akan berkolaborasi dalam rangka untuk menyimpan data eksternal (data dosen). PHP menyajikan interface/antarmuka untuk user kemudian dihubungkan dengan server DBMS MySQL supaya data bisa disimpan didalamnya. Proses penilaian kinerja dosen dilakukan menggunakan metode Weighted Product, dimana terdapat kriteria dan bobot untuk mencari nilai vektor $\mathrm{s}$ kemudian nilai tersebut digunakan untuk mencari nilai vektor v.

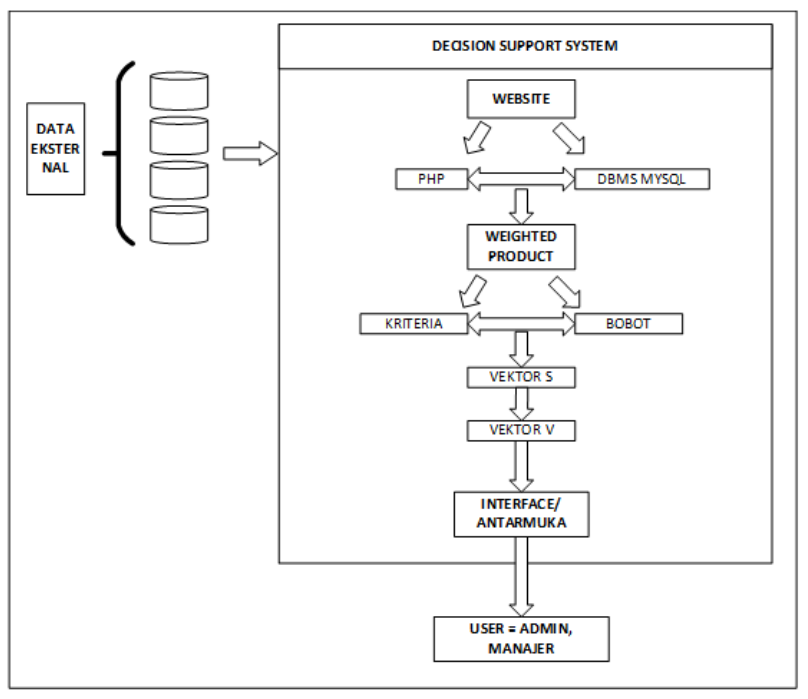

Gambar 2. Arsitektur Decision Support System

Tahapan pembuatan sistem dan pengujian sistem terdiri dari spesifikasi beberapa perangkat keras (hardware) dan perangkat lunak (software) untuk mendukung pembuatan Decision Support System penilaian kinerja dosen. Pengujian sistem dilakukan dengan data sebenarnya dosen di Universitas Brawijaya. 
Tahapan implementasi sistem dilakukan kepada manajer yakni orang yang memiliki peran pada kinerja dosen di Universitas Brawijaya yakni rektor atau dekan. Bisa dilakukan dengan pihak yang biasa melakukan penilaian kinerja dosen seperti Gugus Jaminan Mutu (GJM) Fakultas Ilmu Komputer Universitas Brawijaya.

\section{HASIL DAN PEMBAHASAN}

\section{A. Pemodelan Sistem}

Pemodelan sistem merupakan diagram kinerja sistem atau bisa dikatakan alur dari sistem yang dibuat. Diagram ini dibuat supaya memperjelas pemahaman user mengenai alur dari sistem yang berjalan.

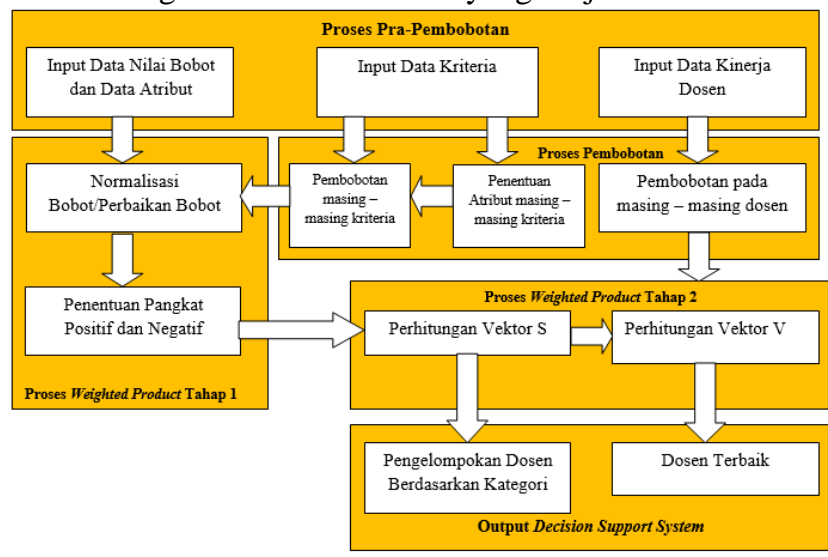

Gambar 3. Pemodelan Sistem

Sesuai pada Gambar 3 pemodelan sistem terdiri dari beberapa bagian antara lain proses pra-pembobotan, proses pembobotan, proses perhitungan dengn metode Weighted Product, dan tahap perangkingan serta pengelompokan dosen berdasarkan kategori.

Proses pra-pembobotan merupakan proses sebelum pembobotan dimana dilakukan proses memasukkan data nilai bobot, data atribut, data kriteria dan data kinerja dosen. Data kriteria merupakan data kriteria dosen sendiri sesuai dengan P2KP dan BKD dosen.

Proses pembobotan merupakan tahap masukan nilai bobot masing-masing dosen berdasarkan kriteria yang ada dan tahap masukan nilai bobot pada masing-masing kriteria. Pada tahap ini juga proses penentuan jenis atribut pada masing - masing kriteria.

Proses metode Weighted Product tahap 1 terdiri dari 2 proses antara lain proses perbaikan bobot/normalisasi dan penentuan pangkat positif dan negatif. Proses perbaikan bobot merupakan proses pembagian masingmasing nilai bobot pada kriteria kemudian dibagi dengan jumlah total nilai bobot seluruh kriteria. Proses penentuan pangkat positif dan negatif disesuaikan dengan jenis atribut pada masing-masing kriteria. Atribut benefit bernilai positif sedangkan cost bernilai negatif.

Proses metode Weighted Product tahap 2 tidak lain adalah proses inti dari metode Weighted Product. Proses ini terdiri dari 2 bagian yakni perhitungan vektor $\mathrm{v}$ dan perhitungan vektor s. Perhitungan vektor S merupakan perkalian dari masing nilai bobot yang dipangkatkan sesuai kriteria dan dimiliki oleh setiap dosen kemudian dijumlahkan seluruhnya. Proses vektor V merupakan nilai dari masing - masing vektor s dari setiap dosen dibagi dengan jumlah keseluruhan vektor $\mathrm{S}$.

Proses terakhir adalah hasil atau output dari metode Weighted Product yakni berupa pengelompokan dosen dan dosen terbaik. Pengelompokan dosen terdiri dari 3 kategori yakni dosen dengan kategori kurang, sedang/normal, dan kurang yang berasal dari nilai vektor S. Sedangkan dosen terbaik yakni ditentukan berdasarkan vektor $\mathrm{V}$ yang dimiliki

\section{B. Kriteria}

Kriteria pada komponen P2KP dan BKD ditunjukkan pada Tabel I dibawah ini.

Tabel 1. Pengelompokan Kriteria

\begin{tabular}{clc}
\hline No & Kriteria & Kelompok \\
\hline 1 & Melaksanakan perkuliahan & P2KP \\
\hline 2 & Membimbing seminar mahasiswa & P2KP \\
\hline 3 & $\begin{array}{l}\text { Membimbing Praktek Kerja } \\
\text { Lapangan }\end{array}$ & P2KP \\
\hline 4 & $\begin{array}{l}\text { Membimbing mahasiswa menyusun } \\
\text { Tugas Akhir }\end{array}$ & P2KP \\
\hline 5 & $\begin{array}{l}\text { Menguji pada ujian akhir } \\
\text { Komprehensif mahasiswa }\end{array}$ & P2KP \\
\hline 6 & Membuat Modul & P2KP \\
\hline 7 & $\begin{array}{l}\text { Melaksanakan penelitian yang } \\
\text { dipublikasi dalam majalah ilmiah } \\
\text { nasional terakreditasi }\end{array}$ & P2KP \\
\hline 8 & $\begin{array}{l}\text { Menulis Karya Ilmiah pada jurnal } \\
\text { Nasional tidak Akreditasi }\end{array}$ & P2KP \\
\hline 9 & $\begin{array}{l}\text { Menulis satu judul buku yang } \\
\text { diterbitkan secara nasional }\end{array}$ & P2KP \\
\hline 10 & $\begin{array}{l}\text { Memberi latihan/penyuluhan pada } \\
\text { masyarakat }\end{array}$ & BKD \\
\hline 11 & $\begin{array}{l}\text { Membuat/Menulis karya pengabdian } \\
\text { kepada masyarakat }\end{array}$ & BKD \\
\hline 12 & $\begin{array}{l}\text { Memberikan jasa konsultan yang } \\
\text { relevan dengan kepakarannya }\end{array}$ & BKD \\
\hline 13 & $\begin{array}{l}\text { Menulis karya pengabdian yang } \\
\text { dipakai sebagai modul pelatihan oleh } \\
\text { seorang dosen }\end{array}$ & BKD \\
\hline 14 & $\begin{array}{l}\text { SKS dosen dengan beban tugas } \\
\text { tambahan selain dosen tetap }\end{array}$ & BKD \\
\hline 15 & $\begin{array}{l}\text { Bimbingan akademik setiap 12 } \\
\text { mahasiswa }\end{array}$ & $\begin{array}{l}\text { Bimbingan dan Konseling terhadap } \\
\text { setiap 12 mahasiswa }\end{array}$ \\
\hline 17 & Menjadi anggota panitia Wisuda \\
\hline 18 & Peserta seminar/workshop & BKD \\
\hline & & \\
\hline 16 & BKD \\
\hline
\end{tabular}

Sesuai pada Tabel 1, kriteria berjumlah 18 kemudian dikelompokkan menjadi 2 antara lain kriteria yang masuk kelompok P2KP dan kriteria yang masuk kelompok BKD.

\section{Hasil Pengujian}

Pada proses memasukkan data BKD (Beban Kinerja Dosen) ke dalam Decision Support System terlebih dahulu dilakukan pemetaan terhadap nilai yang dimasukkan. Pada komponen kriteria BKD (Beban Kinerja Dosen), data yang diperoleh merupakan data nilai kinerja dosen dalam bentuk sks. Dari nilai dalam bentuk sks tersebut dilakukan pemetaan supaya nilai yang dimasukkan ke dalam sistem sesuai dengan model data sistem yakni nilai interval 10 sampai 100. Dibawah ini disajikan beberapa proses pemetaan nilai sks BKD. 
Tabel 2. Perhitungan Nilai Beban Kinerja Dosen

\begin{tabular}{|c|c|c|}
\hline No & Kriteria & Hasil \\
\hline 1 & $\begin{array}{l}\text { Memberi latihan/penyuluhan } \\
\text { pada masyarakat }\end{array}$ & $\begin{array}{l}4 \text { sks }=100 \\
1 \text { sks }=25 \\
3 \text { sks }=75 \\
0=10\end{array}$ \\
\hline 2 & $\begin{array}{l}\text { Membuat/Menulis karya } \\
\text { pengabdian kepada masyarakat }\end{array}$ & $\begin{array}{l}2 \mathrm{sks}=100 \\
1 \mathrm{sks}=50 \\
1,2 \mathrm{sks}=60 \\
1,5 \mathrm{sks}=75 \\
1,8 \mathrm{sks}=90 \\
0=10 .\end{array}$ \\
\hline 3 & $\begin{array}{l}\text { Memberikan jasa konsultan } \\
\text { yang relevan dengan } \\
\text { kepakarannya }\end{array}$ & $\begin{array}{l}3 \mathrm{sks}=100 \\
1 \mathrm{sks}=33 \\
2 \mathrm{sks}=66 \\
0=10\end{array}$ \\
\hline 4 & $\begin{array}{l}\text { Menulis karya pengabdian yang } \\
\text { dipakai sebagai modul pelatihan } \\
\text { oleh seorang dosen }\end{array}$ & $\begin{array}{l}2 \mathrm{sks}=100 \\
1 \mathrm{sks}=50 \\
1,2 \mathrm{sks}=60 \\
1,5 \mathrm{sks}=75 \\
0=10\end{array}$ \\
\hline 5 & $\begin{array}{l}\text { SKS dosen dengan beban tugas } \\
\text { tambahan selain dosen tetap }\end{array}$ & $\begin{array}{l}4 \mathrm{sks}=100 \\
1 \mathrm{sks}=25 \\
2 \mathrm{sks}=50 \\
3 \mathrm{sks}=75 \\
0=10\end{array}$ \\
\hline 6 & $\begin{array}{l}\text { Bimbingan akademik setiap } 12 \\
\text { mahasiswa }\end{array}$ & $\begin{array}{l}1 \text { sks }=100 \\
(12 \text { mahasiswa }) \\
2 \text { sks }=80 \\
(24 \text { mahasiswa }) \\
3 \text { sks }=60 \\
(36 \text { mahasiswa }) \\
4 \text { sks }=40 \\
(48 \text { mahasiswa }) \\
5 \text { sks }=20 \\
(60 \text { mahasiswa }) \\
0=10\end{array}$ \\
\hline 7 & $\begin{array}{l}\text { Bimbingan dan Konseling } \\
\text { terhadap setiap } 12 \text { mahasiswa }\end{array}$ & $\begin{array}{l}1 \mathrm{sks}=100 \\
(12 \mathrm{mahasiswa}) \\
2 \mathrm{sks}=80 \\
(24 \text { mahasiswa }) \\
3 \mathrm{sks}=60 \\
(36 \text { mahasiswa }) \\
4 \text { sks }=40 \\
(48 \text { mahasiswa }) \\
5 \text { sks }=20 \\
(60 \text { mahasiswa }) \\
0=10\end{array}$ \\
\hline 8 & Peserta seminar/workshop & $\begin{array}{l}1 \mathrm{sks}=100 \\
0,5 \mathrm{sks}=50 \\
0=10\end{array}$ \\
\hline
\end{tabular}

Sesuai pada Tabel 2 diatas ditunjukkan nilai masingmasing kriteria khusus kategori BKD yang awalnya dalam bentuk sks kemudian dilakukan pemetaan menjadi nilai yang intervalnya mulai 10 sampai 100 .

Pada proses memasukkan data P2KP (Penilaian Prestasi Kerja Pegawai) ke dalam Decision Support System terlebih dahulu dilakukan pemetaan terhadap nilai yang dimasukkan. Proses perhitungan sesuai dengan Ketentuan Pelaksanaan Peraturan Pemerintah Nomor 46 Tentang Penilaian Prestasi Kerja Pegawai Negeri Sipil. Aspek penilaian sesuai dengan peraturan tersebut pada Sasaran Kinerja Pegawai (SKP) adalah kuantitas, kualitas dan waktu.Sebenarnya terdapat aspek biaya namun pada kriteria yang terdapat pada penelitian ini tidak membutuhkan biaya. Unsur yang terdapat pada penilaian ini adalah target dan realisasi. Target merupakan jumlah beban kerja yang akan dicapai dari setiap pelaksanaan tugas jabatan. Sedangkan Realisasi merupakan jumlah beban kerja yang telah dicapai dari setiap pelaksanaan tugas jabatan. Dibawah ini pada Tabel 3 disajikan perhitungan atau rumus penilaian capaian SKP (Sasaran Kinerja Pegawai).

Tabel 3. Perhitungan Nilai Penilaian Prestasi Kerja Pegawai

\begin{tabular}{cll}
\hline No & Perhitungan/Rumus & Keterangan \\
\hline 1 & Kuantitas $=\underline{\mathrm{Rkn}} \times \mathbf{\mathrm { Tkn }}$ & $\mathrm{Rkn}=$ Realisasi kuantitas \\
& & $\mathrm{Tkn}=$ Target kuantitas \\
\hline 2 & Kualitas $=\underline{\mathrm{Rkl}} \times 100$ & $\mathrm{Rkl}=$ Realisasi kualitas \\
& & $\mathrm{Tkl}=$ Target kualitas \\
\hline 3 & Waktu $=$ & $\mathrm{NT}=$ Nilai Tertimbang $=$ \\
& NT.TW $-\mathrm{RW} \times 100$ & 1,76 \\
& TW & $\mathrm{RW}=$ Realisasi Waktu \\
& & $\mathrm{TW}=$ Target Waktu \\
\hline
\end{tabular}

Sebelum melakukan pengujian data proses mencari nilai standar perlu dilakukan untuk menentukan range dosen pada kategori sedang/normal. Standar yang digunakan berasal dari BKD yakni sebagai berikut :

Tabel 4. Standar Minimal BKD Sesuai Perundangan

\begin{tabular}{lll}
\hline No & Nama Bidang & $\begin{array}{l}\text { Jumlah Minimal } \\
\text { SKS }\end{array}$ \\
\hline 1 & Pendidikan dan Penelitan & 18 \\
\hline 2 & $\begin{array}{l}\text { Pengabdian Masyarakat dan } \\
\text { Kegiatan Penunjang }\end{array}$ & 6 \\
\hline
\end{tabular}

Pada Tabel 4 diatas sesuai syarat perundangan, sks dari bidang pendidikan dan penelitian lebih dari sama dengan 18 sks $(>=18)$ atau bisa dikatakan minimal nilainya 18 sks. Tugas melakukan pendidikan dan penelitian paling sedikit sepadan dengan 9 sks. Sedangkan sks dari bidang pengabdian masyarakat dan kegiatan penunjang lebih dari sama dengan 6 sks $(>=6)$ atau bisa dikatakan minimal nilainya 6 sks. Untuk jumlah nilai keseluruhan pada Beban Kinerja Dosen (BKD) tidak boleh lebih dari 32 sks. Namun pada Decision Support System dalam penelitian ini, kriteria BKD masuk dalam 2 bidang saja karena kriteria lain masuk dalam bidang P2KP. Bidang BKD yang dimaksud adalah bidang Pengabdian Masyarakat dan bidang Kegiatan Penunjang, sehingga jumlah minimal sks adalah 6 sks.

Setelah standar normal diperoleh maka bisa ditentukan range dosen sebanyak 3 kategori yakni sesuai pada Tabel 5 dibawah ini :

Tabel 5. Range Nilai Dosen Berdasarkan Vektor S

\begin{tabular}{cll}
\hline No & Kategori & Range Nilai \\
\hline 1 & Dosen Kategori Kurang & 20 sampai29,99 \\
\hline 2 & Dosen Kategori Normal & 30 sampai 39,99 \\
\hline 3 & Dosen Kategori Baik & 40 sampai 50 \\
\hline
\end{tabular}

Pengujian dilakukan dengan data 20 dosen dengan kategori yang sesuai dengan penilaiannya. Pengelompokan dosen berdasarkan kategori sesuai dengan range yang telah ditentukan sebelumnya menggunakan metode Weighted Product.

Tabel 6. Hasil Pengujian

\begin{tabular}{cccl}
\hline No & Dosen & Vektor S & Kategori \\
\hline 1 & Dosen 1 & 33.57879624 & Dosen Kategori Normal \\
\hline 2 & Dosen 2 & 34.69609215 & Dosen Kategori Normal \\
\hline 3 & Dosen 3 & 39.74700074 & Dosen Kategori Normal \\
\hline 4 & Dosen 4 & 38.50281494 & Dosen Kategori Normal \\
\hline
\end{tabular}




\begin{tabular}{cccl}
\hline No & Dosen & Vektor S & Kategori \\
\hline 5 & Dosen 5 & 31.05686818 & Dosen Kategori Normal \\
\hline 6 & Dosen 6 & 34.90764378 & Dosen Kategori Normal \\
\hline 7 & Dosen 7 & 32.07146634 & Dosen Kategori Normal \\
\hline 8 & Dosen 8 & 32.33267342 & Dosen Kategori Normal \\
\hline 9 & Dosen 9 & 30.45014141 & Dosen Kategori Normal \\
\hline 10 & Dosen 10 & 30.70077762 & Dosen Kategori Normal \\
\hline 11 & Dosen 11 & 30.02388018 & Dosen Kategori Normal \\
\hline 12 & Dosen 12 & 46.94149097 & Dosen Kategori Baik \\
\hline 13 & Dosen 13 & 32.56062825 & Dosen Kategori Normal \\
\hline 14 & Dosen 14 & 30.57015051 & Dosen Kategori Normal \\
\hline 15 & Dosen 15 & 30.35414283 & Dosen Kategori Normal \\
\hline 16 & Dosen 16 & 30.97346768 & Dosen Kategori Normal \\
\hline 17 & Dosen 17 & 49.40209483 & Dosen Kategori Baik \\
\hline 18 & Dosen 18 & 47.76388262 & Dosen Kategori Baik \\
\hline 19 & Dosen 19 & 35.40454915 & Dosen Kategori Normal \\
\hline 20 & Dosen 20 & 33.74794099 & Dosen Kategori Normal \\
\hline
\end{tabular}

Sesuai pada Tabel 6 dosen yang dihasilkan dikelompokkan menjadi beberapa kategori sesuai dengan jumlah nilai yang dimiliki oleh masing-masing dosen. Pada Tabel 4 seluruh dosen masuk dalam kategori sedang/normal dan kategori baik.

\section{KESIMPULAN}

Sesuai pengujian pada bab sebelumnya, pada Decision Support System ini mampu menghasilkan dosen dengan 3 kategori yakni kurang, sedang/normal, dan baik. Pembagian kategori tersebut berdasarkan range nilai dosen dari nilai vektor $S$ pada metode Weighted Product. Pembagian range nilai ini diawali dengan menentukan batasan minimal atau batasan standar nilai BKD dosen yang telah ditentukan oleh perundangan. Pada pengujian yang terakhir, seluruh dosen masuk pada kategori sedang/normal dan baik. Sehingga tidak ada satupun dosen masuk dalam kategori kurang karena data dari BKD sudah masuk standar dosen yang ideal, yakni kewajibannya menjadi seorang dosen sudah terpenuhi. Kewajiban yang dimaksud adalah segala kewajiban yang masuk dalam bidang Tridharma Perguruan Tinggi.

\section{DAFTAR PUSTAKA}

[1] Direktorat Jenderal Pendidikan Tinggi Kementerian Pendidikan Nasional dan Kebudayaan, Pedoman Beban Kerja Dosen dan Evaluasi Pelaksanaan Tridharma Perguruan Tinggi, 2012

[2] Anonymous,Penilaian Prestasi Kerja PNS, 2015, [Online], http://pemerintah.net/penilaian-prestasi-kerja-pns/

[3] Peraturan Pemerintah Republik Indonesia, Penilaian Prestasi Kerja Pegawai Negeri Sipil, 2011

[4] Kusumadewi, Sri. Hartati, S. Harjoko, A. dan Wardoyo, R,Fuzzy Multi-Attribute Decision Making (FUZZY MADM). Yogyakarta: Penerbit Graha Ilmu, 2006

[5] O, Remigiusz,Small Enterprise's Computer Network Design Using Basic MCDM Methods, Journal of Information Control and Management Systems, 2014

[6] Burstein, F.dan Holsapple, C.W.,Handbook on DecisionSupport System 1, Springer, Heidelberg 2008

[7] Turban. E, Aronson. Jay E, Liang.T, Decision Support Systems And Intelligent Systems $7^{\text {th }}$ Edition, India : Prentice-Hall Of India, 2007

[8] Mateo,J. R. San Cristóbal,Multi-Criteria Analysis in the Renewable Energy Industry, Springer-Verlag London Limited, 2012

[9] Badan Kepegawaian Negara, Ketentuan Pelaksanaan Peraturan Pemerintah Nomor 46 Tahun 2011 Tentang Penilaian Prestasi Kerja Pegawai Negeri Sipil, 2013 